\title{
Abies pinsapo forests in Spain and Morocco: threats and conservation
}

\author{
L.G. Esteban, P. De Palacios and L. Rodríguez-Losada Aguado
}

\begin{abstract}
The conifer forests of the Mediterranean Basin have been subjected to overuse by humans since ancient times. Some species have survived in inaccessible refuges but the ranges of other species have been greatly reduced by the effects of clearance for agriculture, livestock raising, illegal felling and, in some cases, fire. The firs are no exception and some now exist only as relict species. Abies pinsapo is an example, with the species surviving in only three enclaves in southern Spain and two in northern Morocco. Until the mid 20th century A. pinsapo forests were subject to major anthropogenic pressures, and in Spain they were under constant threat of overuse until they were acquired by the State. Conservation efforts have now, however, been undertaken in both Spain and Morocco, and the fact that all the A. pinsapo forests are covered by some form of protection preserves them from further inappropriate use or exploitation. These forests are now recovering after years of intensive grazing and use of their timber for construction, firewood and charcoal making. However, these relict forests face the new threats of climate change, arson and the appearance of pests. The limited area occupied by these forests makes them highly vulnerable to disturbance.
\end{abstract}

Keywords Abies pinsapo, conifer, forest, Mediterranean, Morocco, fir, Spain, threats

\section{Introduction}

$\mathrm{T}$ he biodiverse mountainous areas of the Mediterranean region (Cowling et al., 1996) were a refuge for certain conifer taxa (species of Abies, Cedrus, Cupressus, Juniperus and Pinus) during glacial periods (Bennett et al., 1991). Some of these taxa have been widely used as sources of wood and food (Farjon et al., 1993) and, as a result, many of these mountain conifers have been overexploited and are now of considerable conservation concern.

In the Taurus Mountains of Turkey, particularly around the ancient city of Sagalassos, the forests have been subjected to human use for thousands of years (Vanhaverbeke \& Waelkens, 2003, cited in Fontaine et al., 2007) and

L.G. Esteban (Corresponding author), P. DE PAlacios and L. RodríguezLosada Aguado Universidad Politécnica de Madrid, Escuela Técnica Superior de Ingenieros de Montes, Departamento de Ingeniería Forestal, Ciudad Universitaria, 28040 Madrid, Spain. E-mail luis.garcia@ upm.es

Received 11 September 2008. Revision requested 6 January 2009.

Accepted 23 February 2009. inappropriate silvicultural practices continue to threaten Abies cilicica (Fontaine et al., 2007). In Lebanon 10 conifer species are threatened to varying degrees by fragmentation and deterioration of their habitat (Talhouk et al., 2001). Elsewhere in the eastern Mediterranean Abies nordmanniana subsp. equi-trojani, Abies borisii-regis and some populations of Pinus heldreichii require management plans to guarantee their survival, as do the populations of Cedrus brevifolia in Cyprus (Quézel \& Barbero, 1990). Most of the conifer forests in the southern Mediterranean are threatened as a result of deforestation and overgrazing (Barbero et al., 1990). In the Maghreb of Morocco there is particular concern for Abies numidica, Abies pinsapo var. tazaotana, Pinus nigra subsp. mauritanica, Cupressus atlantica, Cedrus atlantica, Tetraclinis articulata and Juniperus thurifera (Quézel \& Barbero, 1990; Quézel, 1991).

In Spain human activity and climate change are affecting the regeneration of Juniperus communis in the south-east mountains (García et al., 1998). In northern Sicily Abies nebrodensis has been reduced to 29 individuals (Parducci et al., 2001) and the species is categorized as Critically Endangered on the IUCN Red List (Farjon et al., 2006). A. numidica in Algeria and A. pinsapo var. tazaotana in Morocco are categorized as Vulnerable (Conifer Specialist Group, 1998). Although the other Mediterranean firs are categorized as Lower Risk (i.e. they have been assessed and found not to be in danger of extinction), they still face the threats common to all Mediterranean mountain conifer forests, i.e. the combination of felling (often illegal), livestock raising, farming and repeated fires.

From the time A. pinsapo was described by Boissier in 1837 (Barbey, 1931) until forests containing the species were protected by a variety of measures in the 1970 s the species was subject to intense human pressure that fragmented and reduced its area of extent in both Spain and Morocco. The descriptions of the two Moroccan varieties were made in the early 2oth century. Var. marocana was described by Ceballos \& Martín-Bolaños (1928) and var. tazaotana by Sánchez-Cózar (1946). It is likely that the isolation of these populations from human influence until the 19th century, due to difficulties of access, and the low mechanical properties of their wood in comparison with pine, are responsible for their survival.

However, the original area of A. pinsapo is now greatly reduced by timber harvesting, fire and overgrazing. Although felling for timber was not the principal cause of the reduction in extent of $A$. pinsapo forests, both single-species and mixed, there are records of timber occasionally being 
removed illegally, or without silvicultural criteria, and the natural structure of the forest has consequently been modified (Soto, 2006). Greater damage was caused by overgrazing, which prevented natural regeneration, particularly in sites with poor soil or in full sun (Ceballos \& Vicioso, 1933). Fire has also destroyed A. pinsapo forests and caused a decline in their area of extent (Vega, 1999).

Although A. pinsapo forests are now protected they are still threatened, particularly by fire and climate change. Although A. numidica and A. pinsapo may be more resistant to climate change than the other circum-Mediterranean firs, because they adapt better to dry periods (Aussenac, 2002), the presence of pests associated with climate change could endanger their survival.

Here we review the current distribution of A. pinsapo, describe the effects of previous human influences on the species and the threats it now faces, and describe the conservation efforts so far undertaken and those still required.

\section{Distribution and ecology}

A. pinsapo has a very limited area of distribution. It is found in only five enclaves: three in the south of Spain and two in the north of Morocco.

\section{Populations in Spain}

A. pinsapo occurs in three areas in the high mountain ranges of the westernmost part of the Betic Cordillera, in Serranía de Ronda, spanning the provinces of Málaga and Cádiz (Fig. 1). The species occurs in shaded locations with a northerly or occasionally easterly or north-easterly exposure (Ceballos \& Ruiz de la Torre, 1979).

In Málaga the species occurs at $1,000-1,800 \mathrm{~m}$ in the humid Mediterranean vegetation zone. The A. pinsapo forest in Los Reales de Sierra Bermeja (Fig. 1c), comprising 50 ha in 1933 (Ceballos \& Vicioso, 1933), is in the municipalities of Genalguacil, Estepona and Casares, at altitudes of $1,300-1,400 \mathrm{~m}$ on peridotites. In 2008 this A. pinsapo forest occupied an area of only c. 35 ha and was in regression because of major fires in the area, which have divided it into three groves. Sierra de las Nieves is the most extensive area of $A$. pinsapo in the province of Málaga (Fig. 1b, Plate 1a). It extends over the municipalities of Ronda, Tolox and Yunquera at altitudes of 1,000-1,800 m on limestone soils. There are also isolated groves in the ranges of Alcor, Caparaín, Real, Istán, Río Verde and Gialda (Ceballos \& Vicioso, 1933; Ceballos \& Ruiz de la Torre, 1979). The A. pinsapo forest in Sierra de las Nieves expanded from 1,000 ha in 1933 to 2,871 ha in 2008 .

In the province of Cádiz A. pinsapo is found only in Sierra del Pinar, in the municipality of Grazalema (Fig. 1a, Plate $1 b$ ), where it grows on limestone at altitudes of 1,000-
1,650 m. This forest expanded from 200 ha in 1933 to 418 ha in 2008. Groves and isolated stands are also found in the western part of Monte Prieto, the sides of El Montón and on the northern slopes of Zafalgar and Los Pinos (Ceballos \& Martín-Bolaños, 1930; Ceballos \& Ruiz de la Torre, 1979).

A. pinsapo occurs in locations with average rainfall of $>1,000 \mathrm{~mm}$ but nevertheless copes well with drought, although total rainfall is $>100 \mathrm{~mm}$ during summer in all of its locations (Ceballos \& Ruiz de la Torre, 1979). It grows in locations that have more hours of sunshine than areas where other Mediterranean firs grow and is capable of colonizing steep slopes, including eroded rocky ground. It occurs with drought tolerant oaks (Quercus faginea, Quercus alpestris, Quercus ilex and Quercus suber) and other conifers such as Pinus pinaster, and less commonly with Pinus halepensis, in this case in Sierra de la Yunquera (Ceballos \& Ruiz de la Torre, 1979).

\section{Populations in Morocco}

A. pinsapo occurs in the western Rif in two enclaves (Fig. 1d). The northernmost is on Mount Tazaout (Plate 1d), also known as Yebel Tazaout, in the Beni Sey-yel region, where A. pinsapo var. tazaotana occupied an area of 493 ha at altitudes of $1,400-1,700 \mathrm{~m}$ in 2008 . To the south A. pinsapo var. marocana spans the Chefchaouen mountains (Plate 1c), reaching as far as Ametráx, with a total area of 2,531 ha at altitudes of 1,400-2,100 m (Liu, 1971). The soil on which A. pinsapo grows is limestone. At high altitudes near mountain peaks the trees show signs of limited growth because of the constant winds and shallow soil. The rainfall in the species' area of occurrence averages $>1,000 \mathrm{~mm}$ (Charco, 1999). Unlike the Spanish A. pinsapo forests, those in the Rif rarely form single-species forests but mix with Atlas cedars Cedrus atlantica. In some places the forests comprise firs, cedars and a conifer absent from the Andalusian A. pinsapo forests, Pinus nigra subsp. mauritanica, which is smaller than the P. nigra var. salzmannii found in the Betic Cordillera. In the lower, warmer and dryer areas A. pinsapo occurs with Tetraclinis articulata, Olea marocana and Quercus coccifera, and in the more humid, cooler areas it occurs with Quercus ilex. Of all the firs in the western Mediterranean, A. pinsapo var. tazaotana grows the tallest and has the greatest diameter.

\section{Threats}

\section{Timber harvesting}

Unlike other Mediterranean conifer species, such as Cedrus libani, which have been widely harvested throughout history (Speiser, 1955; Wilson, 1955), A. pinsapo has not been extensively felled for timber. This is probably because of the difficulty of access to the 


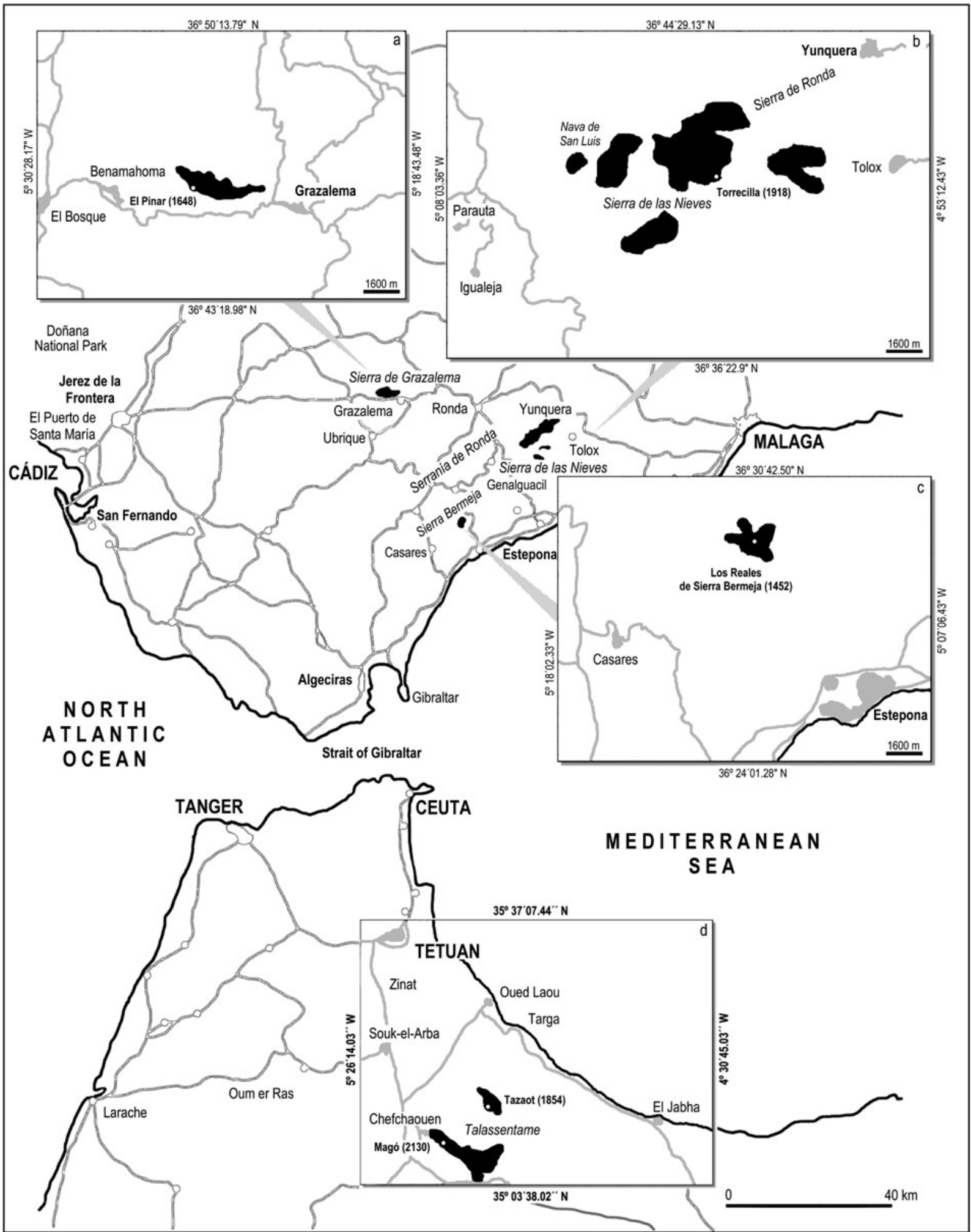

Fig. 1 Distribution of Abies pinsapo forests (black shaded areas), which are restricted to southern Spain and northern Morocco: (a) Sierra de Grazalema (Cádiz), (b) Sierra de las Nieves (Málaga), (c) Los Reales de Sierra Bermeja (Málaga), (d) Tazaout and Talassemtane (Morocco).

forests, the fact that the land occupied by the trees is unsuitable for farming because of the orography, and because $A$. pinsapo timber is no match in quality compared to pine or cedar.
Nevertheless, certain projects at various periods made use of A. pinsapo wood locally (Chapman \& Buck, 1910). There are written records of $A$. pinsapo timber being used in the building of ships in the 16th century and for the 


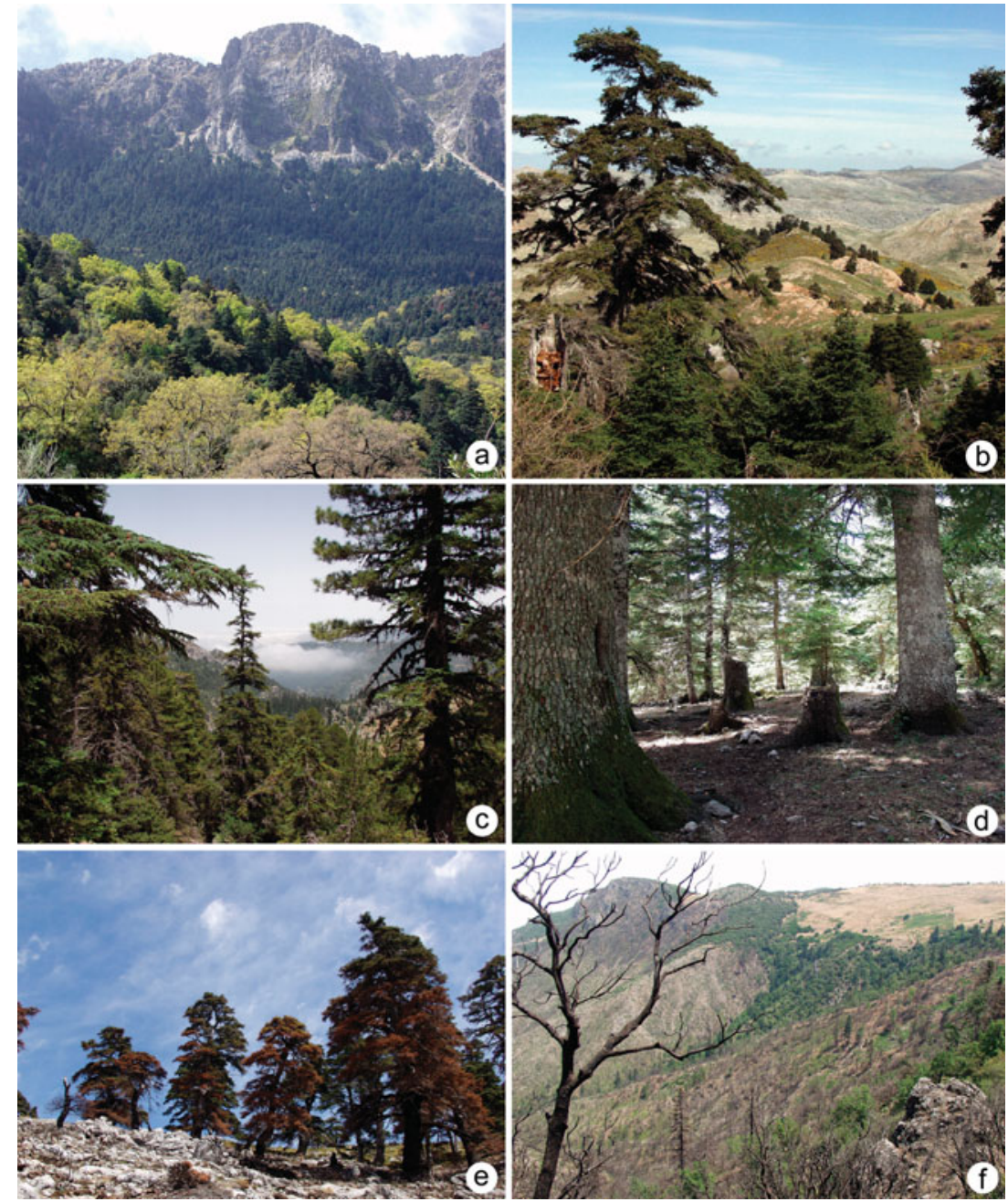

Plate 1 Abies pinsapo forests. (a) Sierra de las Nieves (Spain). (b) Sierra de Grazalema (Spain). (c) Talassemtane National Park (Morocco). (d) Tazaout (Morocco): the stumps remained after the summer of 1946, from A. pinsapo felled for the building of a $\log$ hut as a base from which the Spanish Forest Service made an inventory of Mount Tazaout. (e) Sierra de las Nieves (Spain): a fire in 2004 affected trees in full sun that will not be able to regenerate. (f) Tazaout (Morocco): effects of the 2002 forest fire on the northern slope of Tazaout, in an area of 200 ha (photograph from 2004, showing almost no regeneration).
Algeciras-Ronda-Boadilla railway in the early 2oth century. A. pinsapo was also used for the seating at the bull ring in Ronda (Peraza, 1964; Prioton, 1964), in mining, and in ice pits (in which snow was stored during the winter in alternate layers separated by $A$. pinsapo branches so that the ice that was formed could be used in the summer; Rodríguez, 1999). Much of the timber of $A$. pinsapo forests was used as paper pulp (Ceballos \& Ruiz de la Torre, 1979). Although as fuelwood and charcoal it is of poor quality, A. pinsapo was sometimes used for these purposes locally (Barbey, 1931).

In 1904 and 1905, without following any silvicultural criteria, forest owners in Sierra del Pinar, Grazalema, felled c. 15,000 A. pinsapo for the construction of the first section of the railway line between Ronda and Algeciras. Difficulties encountered in hauling and transporting the logs resulted in most of them being discarded in the forest. In 1906 there was a change of ownership and the refusal of the new owner to let local workers make charcoal with the wood resulted in an intentionally-lit fire that affected 20 ha. In the 1930 s $A$. pinsapo trees were taken from the Berranga and Las Tablas estates, in Sierra de Las Nieves, for the second section of the Ronda-Boadilla railway line. In Villaluenga del Rosario, in the province of Cádiz, a 1 ha stand was destroyed for making charcoal in 1931 (Soto, 2006).

Logging, in accordance with controlled logging plans, occurred in the A. pinsapo forests of the Rif in the first half of the 2oth century, when Spain held the area as a Protectorate (Charco, 1999). The protective measures that apply to the A. pinsapo forests in Spain and Morocco now prohibit logging, and felling is only permitted for the purpose of creating fire-breaks.

Fire

The earliest recorded loss of $A$. pinsapo forests due to fire is from 1570 (Hurtado de Mendoza, 1842). In Sierra de Alcaparaín (municipality of Carratraca), Ceballos \& Vicioso (1933) cite the disappearance in c. 1920 of the group of A. pinsapo trees listed by Laguna (1884), as a result of repeated fires. A stand of c. 1 ha on the bank of the Guadaiza River in Sierra Palmitera disappeared as a result of fire in 1975. In 1991 fire destroyed 1,000 ha of maritime 
pine Pinus pinaster and scrub in Sierra Blanca and Sierra Real, in addition to all the A. pinsapo trees in Sierra Real, some of which were 360 years old.

In Sierra Bermeja forest fires have fragmented and degraded the enclave of $A$. pinsapo, reducing the area of 50 ha in 1933 (Ceballos \& Vicioso, 1933) to 35 ha in 2008. In the summer of 2004 fire destroyed an old stand with a south-east exposure in Sierra de las Nieves (Plate 1e) that cannot be restored because of the southerly exposure. A fire on the northern slope of Tazaout in 2002 affected an area of 200 ha. A visit to the area in 2004 confirmed that there was almost no regeneration because of the steep slope and competition from less demanding species (Plate 1f).

Although A. pinsapo lacks the resprouting ability characteristic of many Mediterranean plants (Keeley, 2006) it reacts to fire by adaptation. The species expands its cover and the diminished solar radiation hinders the build up of inflammable material (Vega, 1999). A. pinsapo is, however, not particularly inflammable (Rodríguez, 1999).

Until the second half of the 2oth century grazing and charcoal making were the two main causes of fire in the $A$. pinsapo forests. Fires now normally only occur as a result of carelessness or arson. Although some groves of $A$. pinsapo have been lost as a result of fire (Soto, 2006) some, such as the Grazalema forest, have not been affected by fire for nearly 100 years (Arista, 1995).

From 1968 to 2007 the total loss of A. pinsapo forests was 564.7 ha, whereas during 2004-2008 only 1 ha was lost (López Quintanilla, pers. comm.). The intervals of time between the fires in Sierra Bermeja, which occurred in 1840 and 1865, and between those of 1932, 1966 and 1973, resulted in a forest with trees of different ages that, in conjunction with the mature trees, gave great stability to the A. pinsapo forest (Vega, 1999).

Fire destroys $700,000-1,000,000$ ha of forest in the Mediterranean Basin every year (Vélez, 2000). Many of the areas recover through the adaptation mechanisms that many Mediterranean species have to fire (Pickett et al., 1987). However, fire-damaged A. pinsapo forests regenerate poorly in shady exposures and are incapable of regenerating in full sun.

\section{Agriculture and livestock}

Agriculture and farming techniques have also contributed to the decrease in the area of A. pinsapo, as in the case of the forests in Lajares and Caina, which were affected by several fires in the 19th century as a result of management of land occupied by vineyards. Fire was also used as a way to renew or increase grazing areas for livestock and this was the reason for the 1928 fire in the A. pinsapo forest in Barranco de los Mármoles, intentionally lit to increase pasture land for goats (Rodríguez, 1999). Pasturing continues under strict control in the three areas of Spanish A. pinsapo forests in Grazalema and Sierra Bermeja but it does not represent the same degree of threat as it did prior to the 1950s (Arista et al., 1997).

Pests

Drought affects the susceptibility of $A$. pinsapo to infestation by pests. The A. pinsapo in Sierra Bermeja have sometimes been infested with the basidiomycete Armillaria mellea, although the forest was never threatened and has fully recovered (Arista et al., 1997). Infestation by the lepidopteran Dioryctria aulloi has also been recorded; its life cycle is strongly influenced by climate, as seen in the incidence of this pest during the drought of 1991-1995 (Arista et al., 1997). However, the irregular annual seed production of $A$. pinsapo provides trees with a natural defence against establishment of this insect. During this drought a more serious attack by the coleopteran Cryphalus numidicus occurred, resulting in the death of some of the trees. In the Yunquera A. pinsapo forest this borer was accompanied by the appearance of the basidiomycete Heterobasidion annosum (Navarro et al., 2003). The $A$. pinsapo forests are also affected by the homopterans Mindarus abietinus, Cinara pectinatae and Cinara confinis (Cobos et al., 1998). The damage caused by C. confinis can lead to the death of twigs and branches.

\section{Other threats}

The fragmentation of the original A. pinsapo forests has led to isolation in small stands and in some cases isolated individuals. The average seed viability of $A$. pinsapo at low densities is only $21 \%$ whereas in dense forests it can be $82 \%$ (Arista \& Talavera, 1996). The formation of biogeographical islands (MacArthur \& Wilson, 1967) causes progressive deterioration in the genetic variability of $A$. pinsapo, leading to endogamy (Arista \& Talavera, 1996). Lower rainfall and higher evapotranspiration because of climate change are a potential threat. In the early 1990 s several A. pinsapo died from a combination of water stress and the appearance, propitiated by climate, of pests (Génova, 2007).

\section{Discussion}

The climate dynamics of the Strait of Gibraltar and the mountains on both sides of the Strait make the area a favourable enclave for $A$. pinsapo. The mist, high rainfall and altitudes up to 2,000 $\mathrm{m}$ give rise to unique bioclimatic conditions. Although the Spanish A. pinsapo are smaller than those of the Rif, in Sierra Bermeja they are more similar in shape to the firs of the Rif than to those of Grazalema or Sierra de las Nieves. The wood of the Moroccan varieties and the Sierra Bermeja A. pinsapo is also similar (Esteban et al., 2007). However, the trees in the 
TABLE 1 International and national regulations for the conservation of Abies pinsapo in Spain and Morocco.

\begin{tabular}{|c|c|c|c|c|}
\hline Organization & Regulation & Date & Scope & Details \\
\hline \multicolumn{5}{|l|}{ International regulations } \\
\hline UNESCO & Biosphere Reserve & 1977 & Sierra de Grazalema & Protection of 300 ha of A. pinsapo \\
\hline European Union & Council Directive 92/43/CEE & 21 May 1992 & $\begin{array}{l}\text { Forest ecosystems } \\
\text { that include } A \text {. pinsapo }\end{array}$ & $\begin{array}{l}\text { Inclusion of } A \text {. pinsapo forests whose } \\
\text { preservation requires creation of } \\
\text { special conservation zones }\end{array}$ \\
\hline UNESCO & Biosphere Reserve & 1995 & Sierra de las Nieves & Relict $A$. pinsapo forest \\
\hline European Union & Council Directive 92/43/CEE & 19 July 2006 & $\begin{array}{l}\text { List of places of } \\
\text { community interest } \\
\text { in Mediterranean } \\
\text { biogeographical region }\end{array}$ & $\begin{array}{l}\text { Protection of Sierra de Grazalema } \\
\text { (ES0000031), Sierra de las } \\
\text { Nieves (ES6170006) \& } \\
\text { Los Reales de Sierra Bermeja } \\
\text { (ES6170004) }\end{array}$ \\
\hline \multicolumn{5}{|l|}{ National regulations } \\
\hline Andalusian Parliament (Spain) & $\begin{array}{l}\text { Creation of Sierra de Grazalema } \\
\text { Natural Park }\end{array}$ & 18 Dec. 1984 & Sierra de Grazalema & $\begin{array}{l}\text { Ecosystem is conserved \& } \\
\text { protected from previous abuse. } \\
\text { Legal protection of Sierra } \\
\text { de Grazalema }\end{array}$ \\
\hline Andalusian Parliament (Spain) & $\begin{array}{l}\text { Ratification of UMMP }{ }^{1} \text { for } \\
\text { Sierra de Grazalema Natural Park }\end{array}$ & 27 Dec. 1988 & Sierra de Grazalema & $\begin{array}{l}\text { Management \& recovery of } \\
\text { A. pinsapo forests }\end{array}$ \\
\hline Andalusian Parliament (Spain) & $\begin{array}{l}\text { Inventory of Protected Natural Areas in } \\
\text { Andalusia; Creation of Sierra de las Nieves } \\
\text { Natural Park \& Los Reales de } \\
\text { Sierra Bermeja Natural Site }\end{array}$ & 18 July 1989 & $\begin{array}{l}\text { The three Spanish } \\
\text { A. pinsapo forests }\end{array}$ & $\begin{array}{l}\text { Conservation policies \& economic } \\
\text { development are brought into line }\end{array}$ \\
\hline Andalusian Parliament (Spain) & Law on wild flora \& fauna & 28 Oct. 2003 & $\begin{array}{l}\text { The three Spanish } \\
\text { A. pinsapo forests }\end{array}$ & $\begin{array}{l}\text { A. pinsapo is listed as a } \\
\text { threatened species }\end{array}$ \\
\hline Andalusian Parliament (Spain) & $\begin{array}{l}\text { Ratification of the } \mathrm{NRMP}^{2} \& \\
\mathrm{UMMP}^{1} \text { for Sierra de las Nieves } \\
\text { Natural Park }\end{array}$ & 9 Dec. 2003 & Sierra de las Nieves & The largest Spanish $A$. pinsapo forest \\
\hline Andalusian Parliament (Spain) & $\begin{array}{l}\text { Ratification of the NRMP }{ }^{2} \& \mathrm{UMMP}^{1} \\
\text { for Sierra de Grazalema Natural Park }\end{array}$ & 18 April 2006 & Sierra de Grazalema & $\begin{array}{l}\text { Warning on danger to Spanish } \\
\text { A. pinsapo forests from Heterobasidion } \\
\text { annosum \& Cryphalus numidicus }\end{array}$ \\
\hline $\begin{array}{l}\text { Ministry of Agriculture } \\
\text { (Morocco) }\end{array}$ & Creation of Botanical Reserve & 1972 & Chefchaouen mountains & $\begin{array}{l}\text { A. pinsapo var. marocana comes } \\
\text { under protection }\end{array}$ \\
\hline $\begin{array}{l}\text { High Commission for Water, } \\
\text { Forests \& Desertification Control } \\
\text { (Morocco) }\end{array}$ & Creation of Talassemtane National Park & 2004 & $\begin{array}{l}\text { Rif mountains (provinces } \\
\text { of Chefchaouen \& } \\
\text { Tetuán) }\end{array}$ & $\begin{array}{l}\text { Moroccan varieties are conserved \& } \\
\text { protected }\end{array}$ \\
\hline
\end{tabular}

${ }^{1}$ UMMP, Use and Management Master Plan

${ }^{2}$ NRMP, Natural Resources Management Plan 
Sierra Bermeja A. pinsapo forest are the least tall, and have the smallest diameters and a twisted form. The Yunquera A. pinsapo forest has regenerated well, with a sufficiently high tree density that it requires silvicultural treatment. The Grazalema A. pinsapo forest was threatened by felling and excessive stock raising in the early 2oth century. It now consists of mostly even-aged trees of homogeneous form with high diameters but there is little regeneration.

The Moroccan A. pinsapo forests are in better condition than those in Spain, not only because they have been better preserved because of their isolation from populated areas and the consequently lower anthropogenic impacts, but also because they occur in an area with higher rainfall and a wider altitudinal range. In the event of any climate change the Moroccan A. pinsapo would therefore have a greater chance of persistence. Of all the A. pinsapo forests, Tazaout has the largest trees, attaining heights of up to $50 \mathrm{~m}$ and base diameters of $1.30 \mathrm{~m}$. The vitality of this forest is evident in the intense regeneration and, although $A$. pinsapo is mixed with maples, cedars and maritime pine $P$. pinaster and European black pine Pinus nigra, it is dominant.

The poorer condition of the Spanish A. pinsapo forests leads not only to smaller-sized trees but also to greater vulnerability to pests. The drought of 1991-1995 caused a loss of trees growing in the least favourable conditions and if such droughts recur there are likely to be further such losses. While the exposures in the Betic Cordillera are always northerly, A. pinsapo in Morocco prospers in northerly, westerly and occasion southerly exposures, influenced by the position of the mountains in relation to the incoming direction of the damp Atlantic winds.

Attempts to reforest with this species have not been satisfactory and natural regeneration depends on intense seed dissemination followed by at least 2 years of high rainfall and short, mild summers. In general, however, the A. pinsapo forests are stabilized and recovering after years of intensive goat pasturing, forest fires and use for fuelwood and charcoal making. However, the risk of fire is everpresent and that of climate change is looming. Although Aussenac (2002) suggested that A. pinsapo and A. numidica will be affected less by climate change than other Mediterranean firs because they have adapted to a less favourable environment, if the recent droughts recur the altitude range will progressively decrease and there will be an increased risk of infestation by pests.

Although at the end of the 19th century the forest guards in the municipal forests of Ronda were given responsibility for one of the first initiatives to protect the A. pinsapo forests, conservation measures did not actually begin until 1945, when the three areas of the Ronda A. pinsapo forests were purchased by the Spanish state. This was followed by the 1972 purchase of the Grazalema A. pinsapo forest, which became a Natural Park in 1984. Sierra de las Nieves became a Natural Park in 1989, and the area of Los Reales de Sierra
Bermeja was given the special protection level of Natural Site (Table 1).

The Moroccan A. pinsapo forests are within Talassemtane National Park, where felling is prohibited. In addition, their remote location favours their conservation. The greatest threat besides fire comes from the crops of Indian hemp or hashish Cannabis sativa var. indica, which are increasingly being grown at mid-range altitudes.

All the A. pinsapo forests are now protected and safeguarded from the anthropogenic threats they have been subject to throughout history, with the exception of arson. Conservation efforts now focus on the development of fire prevention plans, including fire-break construction and constant surveillance, and pest control during severe drought. The possibility of undertaking silvicultural treatment is also being considered for some enclaves, to reduce competition among individual trees. In Spain, these initiatives are carried out through the Autonomous Community of Andalusia, Dirección General del Medio Natural, and in Morocco through the Haut Commissariat aux Eaux et Forêts et á La lutte contre la Désertification, Direction Régionale des Eaux et Forêts du Rif à Tetouan, Service Provincial des Eaux et Forêts du Chefchaouen.

\section{Acknowledgements}

We thank the Forestry Engineers Miguel A. Martín Casillas and José López Quintanilla for assistance during our visit to Sierra de las Nieves Natural Park and Sierra Bermeja Natural Site in the province of Málaga, and Sierra de Grazalema Natural Park in the province of Cádiz, Spain, and the Royaume du Maroc Haut Commissariat aux Eaux et Forêts et à la Lutte contre la Désertification, Direction Régionale des Eaux et Forêts du Rif à Tetouan, Service Provincial des Eaux et Forêts du Chefchaouen, in particular Amrani Mohamed, Ingénieur en Chef des Eaux et Forêts du Rif à Tetouan, and Assim El Houssain, Chef du District du Chefchaouen, who provided us with guided access to the forests in Talassemtane and Tazaout (Morocco).

\section{References}

Arista, M. (1995) The structure and dynamics of an Abies pinsapo forest in southern Spain. Forest Ecology and Management, 74, 8189.

Arista, M., Herrera, F.J. \& Talavera, S. (1997) Biología del Pinsapo. Junta de Andalucía, Consejería del Medio Ambiente, Seville, Spain.

Arista, M. \& Talavera, S. (1996) Density effect on the fruit-set, seed crop viability and seedling vigour of Abies pinsapo. Annals of Botany, 77, 187-192.

Aussenac, G. (2002) Ecology and ecophysiology of circumMediterranean firs in the context of climate change. Annals of Forest Science, 59, 823-832.

Barbero, M., Bonin, G., Loisel, R. \& Quézel, P. (1990) Changes and disturbances of forest ecosystems caused by human activities 
in the western part of the Mediterranean basin. Vegetatio, $87,151-$ 173 .

B Arbey, A. (1931) A Travers les Forêts de Pinsapo d'Andalousie: Étude de Dendrologie, de Sylviculture et d'Entomologie Forestière. Librairie Agricole, Paris, France.

Bennett, K.D., Tzedakis, P.C. \& Willis, K.J. (1991) Quaternary refugia of North European trees. Journal of Biogeography, 18, 103-115.

Ceballos, L. \& Martín-Bolaños, M. (1928) El Abeto de Marruecos. Una Excursión al Monte Magó. Vol. III, No. 1 \& 2. Real Sociedad Española de Historia Natural, Madrid, Spain.

Ceballos, L. \& Martín-Bolaños, M. (1930) Estudio sobre la Vegetación Forestal de la Provincia de Cádiz. IFIE, Madrid, Spain.

Ceballos, L. \& Ruiz de la Torre, J. (1979) Árboles y Arbustos de la España Peninsular. Escuela Técnica Superior de Ingenieros de Montes, Madrid, Spain.

Ceballos, L. \& Vicioso, C. (1933) Estudio sobre la Vegetación y la Flora Forestal de la Provincia de Málaga. IFIE, Madrid, Spain.

Chapman, A. \& Buck, W.J. (1910) Unexplored Spain. Arnold, London, UK.

Charco, J. (1999) El Bosque Mediterráneo en el Norte de África. Agencia Española de Cooperación Internacional, Madrid, Spain.

Совоs, J.M., Совоs, P. \& Martínez, G. (1998) Primera cita de la presencia de Cinara confinis (Koch, 1856) (Homoptera, Lachnidae) en las masas naturales de Abies pinsapo Boiss. Boletín Sanidad Vegetal y Plagas, 24, 603-608.

Conifer Specialist Group (1998) Abies pinsapo var. tazaotana. In IUCN Red List of Threatened Species v. 2009.1. Http://www.iucnredlist.org, accessed 25 September 2009.

Cowling, R.M., Rundel, P.W., Lamont, B.B., Arroyo, M.K. \& Arianoutsou, M. (1996) Plant diversity in Mediterraneanclimate regions. Trends in Ecology \& Evolution, 11, 362-366.

Esteban, L.G., De Palacios, P., Guindeo, A. \& García Fernández, F. (2007) Comparative anatomy of the wood of Abies pinsapo and its two Moroccan varieties. IAWA Journal, 28, 285-298.

Farjon, A., Page, C.N. \& Schellevis, N. (1993) A preliminary world list of threatened conifer taxa. Biodiversity and Conservation, 2, 304-326.

Farjon, A., Pasta, S. \& Troìa, A. (2006) Abies nebrodensis. In IUCN Red List of Threatened Species v. 2009.1. Http://www. iucnredlist.org, accessed 25 September 2009.

Fontaine, F., Aerts, R., Özkan, K., Mert, A., Gülsoy, S., Süel, H. et al. (2007) Elevation and exposition rather than soil types determine communities and site suitability in Mediterranean mountain forests of Southern Anatolia, Turkey. Forest Ecology and Management, 247, 18-25.

García, D., Zamora, R., Hódar, J.A. \& Gómez, J.M. (1998) Age structure of Juniperus communis L. in the Iberian peninsula: conservation of remnant populations in Mediterranean mountains. Biological Conservation, 87, 215-220.

Génova, M. (2007) El crecimiento de Abies pinsapo y el clima de Grazalema: aportaciones dendroecológicas. Investigación Agraria: Sistemas y Recursos Forestales, 16, 145-157.

Hurtado de Mendoza, D. (1842) La Guerra de Granada. Imprenta de Juan Olivares, Barcelona, Spain.

Keeley, J.E. (2006) Fire severity and plant age in post-fire resprouting of woody plants in sage scrub and chaparral. Madroño, 53, 373-379.

Laguna, M. (1884) Flora Forestal Española. Ministerio de Fomento, Madrid, Spain.

Liv, T. (1971) A Monograph of the Genus Abies. College of Agriculture, Taiwan University, Taipei, Taiwan.

MacArthur, R.H. \& Wilson, E.O. (1967) The Theory of Island Biogeography. Princeton University Press, Princeton, USA.
Navarro, R.M., Calzado, C., Martínez, M., López, J. \& Trapero, J.A. (2003) Censo de focos de Heterobasidion annosum (Fr) Bref. en ecosistemas de pinsapo. Boletín Sanidad Vegetal y Plagas, 29, 581-592.

Parducci, L., Szmidt, A.E., Madaghiele, A., Anzidei, M. \& Vendramin, G.G. (2001) Genetic variation at chloroplast microsatellites (cpSSRs) in Abies nebroidensis (Lojac.) Mattei and three neighboring Abies species. Theoretical and Applied Genetics, 102, 733-740.

Peraza, C. (1964) Estudio de las Maderas de Coníferas Españolas y de la Zona Norte de Marruecos. IFIE, Madrid, Spain.

Pickett, S.T.A., Collins, S.L. \& Armesto, J.J. (1987) A hierarchical consideration of causes and mechanisms of succession. Plant Ecology, 69, 109-114.

Prioton, J. (1964) Plaidoyer pour le sapin d'Espagne. Revue Forestière Française, 2, 99-114.

Quézel, P. (1991) Structures de végétation et flore en Afrique du Nord: leurs incidences sur les problèmes de conservation. In Conservation des Ressources Végétales (eds M. Rejdali \& V.H. Heywood), pp. 19-32. Actes Éditions, Institut agronomique et vétérinaire Hassan II, Rabat, Morocco.

Quézel, P. \& Barbero, M. (1990) Les forêts méditerranéennes. Problèmes posés par leur signification historique, écologique et leur conservation. Acta Botanica Malacitana, 15, 145-178.

Rodríguez, F. (1999) Los usos tradicionales del monte y sus implicaciones en la aparición de los incendios forestales: una perspectiva desde los pinsapares andaluces. In Incendios Históricos: una Aproximación Multidisciplinar (ed. E. Araque), pp. 313-331. Universidad Internacional de Andalucía, Jaen, Spain.

Sánchez-Cózar, S. (1946) El Abies del Tazaout. Revista de la Real Academia de Ciencias de Madrid, XL, 449-468.

Soto, D. (2006) Núcleos residuales de pinsapo perdidos en Andalucía en el siglo XX. Investigación Agraria: Sistemas y Recursos Forestales, Special issue, 79-86.

Speiser, E.A. (1955) Akkadian myths and epics. In Ancient Near Eastern Texts Relating to the Old Testament, 2nd edition (ed. J.B. Pritchard), pp. 72-99. Princeton University Press, Princeton, USA.

TAlhouk, S.N., ZURAy , R. \& KhURi, S. (2001) Conservation of the coniferous forests of Lebanon: past, present and future prospects. Oryx, 35, 206-215.

Vanhaverbeke, H. \& Waelkens, M. (2003) The Chora of Sagalassos: The Evolution of the Settlement Pattern from Prehistoric until Recent Times (Studies in Eastern Mediterranean Archaeology). Brepols Publishers, Turnhout, Belgium.

Vega, J.A. (1999) Historia del fuego de Pinus pinaster en la cara norte de Sierra Bermeja (Málaga). In Incendios Históricos: una Aproximación Multidisciplinar (ed. E. Araque), pp. 279-307. Universidad Internacional de Andalucía, Jaen, Spain.

Vélez, R. (2000) La Defensa Contra Incendios Forestales. Fundamentos y Experiencias. McGraw-Hill, Madrid, Spain.

Wilson, J.A. (1955) Egyptian historical text. In Ancient Near Eastern Texts Relating to the Old Testament, 2nd edition (ed. J.B. Pritchard), pp. 227-264. Princeton University Press, Princeton, USA.

\section{Biographical sketches}

LUIS G. EsтевAN works in forestry engineering, including the study of the vegetation dynamics of the Spanish forests and human influences on them. PALOMA DE PALACios also works in forestry engineering. The two authors participated for 6 years as Director and Researcher, respectively, in the Spanish television documentary series 
El bosque protector (The Protective Forest), which aimed to make the public aware of the importance of the Spanish forests in the natural, social and economic history of Spain from remote times to the present, and to highlight the negative and serious impact of humans on the state of the forests (see http://www.elbosqueprotector.es). Both authors also conduct research on the anatomy, physics and mechanics of wood. Luis Rodríguez-Losada is currently studying the vegetation dynamics and management of the Spanish forests. 